\title{
Питання психології
}

Дубчак $\boldsymbol{\Gamma}$, доктор психологічних наук, доцент кафедри психології Відкритого міжнародного університету розвитку людини «Україна» (м. Київ)

Сердюк Л., доктор психологічних наук, професор, завідувач лабораторії психології особистості імені П. Р. Чамати Інституту психології імені Г. С. Костюка (м. Київ)

\section{ПОРІВНЯЛЬНИЙ АНАЛІЗ ОСОБЛИВОСТЕЙ СТРЕСОСТІЙКОСТІ СТУДЕНТІВ ТА ФАХІВЦІВ СОЦІОНОМІЧНИХ ПРОФЕСІЙ}

У статті обтрунтовано актуальність вивчення проблеми професійної стресостійкості фахівиів соиіономічних професій. Розкрито зміст поняття «професійна стресостійкість». Описано процедуру дослідження з використанням методики експрес-діагностики рівня психоемоційної напруги (О.Копіна, К.Суслова, Є.Заїкін, 1995) та Бостонського тесту стресостійкості. Представлено результати емпіричного дослідження особливостей стресостійкості і психоемоиійної напруги у студентів, щяо навчаються за соиіономічними професіями та праџюючих фахівиів. Визначено спільні та відмінні особливості стресостійкості майбутніх та пращюючих фахівиів різних соціономічних професій. Виявлено, що студенти більше задоволені свойм здоров'ям, умовами життя, рівнем задоволення основних життевих потреб та життям в иілому, ніж фахівиі. Однак фахівиі характеризуються високою стресостійкістю порівняно зі студентами. Виявлені відмінності є істотними статистично.

Ключові слова: професійна підготовка, сочіономічні професії, стресс, професійна стресостійкість, рівень психічної напруги.

В статье обоснована актуальность изучения проблемьл профессиональной стрессоустойчивости специалистов соииономических профессий. Раскрыто содержание понятия «профессиональная стрессоустойчивость». Описана процедура исследования с использованием методики экспрессдиагностики уровня психоэмочионального напряжения (О.Копина, К.Суслова, Е.Заикин, 1995) и Бостонского теста стрессоустойчивости. Представлень результаты эмпирического исследования особенностей стрессоустойчивости и психоэмочионального напряюжения у студентов, обучаюшихся по сочиономических профессиям и работающих специалистов. Определены общие и отличительные особенности стрессоустойчивости будущих и работающих спещиалистов различных сочиономических профессий. Выявлено, что студенты больше довольны своим здоровьем, условиями жизни, уровнем удовлетворения основных жизненных потребностей и жизнью в иелом, чем специалисты. Однако специалисты характеризуются высокой стрессоустойчивостью сравнению со студентами. Выяяленные различия являются существенныли статистически.

Ключевые слова: профессиональная подготовка, сочиономических профессии, стресс, профессиональная стрессоустойчивость, уровень психического напряжения.

Постановка проблеми у загальному вигляді та їі зв'язок із важливими науковими і практичними завданнями. Вміння успішно справлятися зі стресом i зводити до мінімуму його негативний вплив $\epsilon$ важливим для кожної людини. Передусім, рівень психологічної стійкості особистості виявляється в іiі трудовій діяльності, адже стресостійкість визнається одним із факторів, що впливає на ефективність професійної діяльності. 3 іншого боку, успішна професійна діяльність $є$ основою повноцінного переживання самореалізації, що впливає на задоволеність життям в цілому, на психологічну стійкість.

Особливого значення стійкість до стресу набуває для фахівців соціономічних професій, трудова діяльність яких є одним 3 найбільш напружених в психологічному плані видів трудової активності.

До соціономічних, за визначенням С. О. Климова, належать професії, пов'язані з:

- вихованням, навчанням людей (вихователь, учитель);

- медичним обслуговуванням (лікар, фельдшер, медсестра,);

- побутовим обслуговуванням (продавець, перукар, офіціант);

- інформаційним обслуговуванням (бібліотекар, екскурсовод);

- захистом суспільства i держави (юрист, міліціонер, інспектор, військовослужбовець) [2].

До цієї групи належать також професії, в яких людині доводиться виконувати роботу не в стабільних, а в особливих та екстремальних умовах праці 


\section{Питання психології}

(військовослужбовець, міліціонер та ін.).

Особливими у психології називають такі умови, коли діяльність фахівця пов'язана 3 епізодичною, тобто непостійною, дією екстремальних факторів. До особливих умов праці належать: невизначена ситуація, ситуація 3 ускладненими умовами, ситуація готовності до екстреної дії, ситуація зі зміненими умовами, ситуація ризику [5]. У ситуації з екстремальними умовами має місце постійний вплив екстремальних факторів (брак часу, перевантаження складними завданнями, перенасиченість інформацією та ін.).

На перший погляд, професії цього типу відрізняються відсутністю жорстких і єдиних вимог до самого процесу професійної діяльності, одночасно з цим до представників соціономічних професій висуваються підвищені вимоги.

Варто зазначити, що до фахівців будьякої професії висуваються вимоги двох типів: професійні та психологічні. До професійних вимог можна віднести перелік знань, умінь і навичок, які фіксуються в кваліфікаційній характеристиці або моделі фахівця. Вони забезпечуються спеціальною (предметною) підготовкою людини в середньому або вищому навчальному закладі.

Психологічні вимоги присутні у всіх професіях, забезпечуючи засвоєння i виконання багатьох професійних функцій. У переважній більшості випадків їхня присутність невидима. Однак у соціономічних професіях психологічна відповідність виступає ключовим моментом як на етапі входження людини в діяльність, так i на етапі професійної діяльності. Власне, професії цього типу ставлять високі вимоги до психіки людини, оскільки вони передбачають інтенсивну взаємодію (спілкування) 3 широким колом різних людей.

У зв'язку з цим, гостро постає питання про своєчасну профілактику i корекцію постстресових станів та професійного вигорання, які, в першу чергу, мають грунтуватися на повноцінній діагностиці їх ранніх проявів, а також на виявленні індивідуальної схильності конкретної людини до розвитку дистресу і характерних для неї стратегій подолання складних життєвих ситуацій.
Аналіз останніх досліджень i публікацій. На сьогоднішній день налічується достатня кількість наукових праць, присвячених питанням професійної підготовки майбутніх фахівців (О.Ф. Бондаренко, Т. М. Буякас, I. В. Волженцева, Н. Ю. Волянюк, О. М. Кокун, М. В. Савчин, Т. М. Титаренко та ін.). Проте у працях, в яких досліджувались питання професійної підготовки фахівців соціономічних професій (А. М. Акбава,

Н. О. Антонова,

А. І. Артеменко,

Т. О. Афанасьєва,

К. В. Бабак, Л. І. Дябел,

О. А. Кириленко,

О. В. Лозгачова,

Л. М. Мітіна,

О. Б. Полякова,

C. В. Субботін) представлено лише окремі аспекти цієї проблеми. Проблеми підвищення стресостійкості, як професійно важливої якості фахівців цих професій, висвітлено недостатньо, хоча вона стоїть досить гостро. $\mathrm{He}$ вивченими залишаються механізми становлення професійної стресостійкості фахівців соціономічних професій. Недостатньо вивчено також i вплив індивідуально-типологічних характеристик, особистісних властивостей фахівців з різним рівнем стресостійкості. Така тенденція свідчить про недостатню увагу, яку приділяють дослідники цій проблематиці і обумовлюе наявність прогалини в підготовці спеціалістів соціальноорієнтованих професій.

Метою дослідження став порівняльний аналіз психологічних характеристик стресостійкості студентів та фахівців соціономічних професій, що допоможе зрозуміти механізми становлення професійної стресостійкості майбутніх фахівців соціономічних професій.

\section{Виклад основного матеріалу.} Професійну стресостійкість ми розглядаємо, грунтуючись на методології системного підходу, що дозволяє говорити про структуру психічної реальності - людина професійне середовище, яка, в загальних рисах, розглядається як динамічне ціле [1, 4]. Тому вважаємо, що професійна стресостійкість $є$ інтегральною якістю фахівця як суб'єкта діяльності та необхідна для ефективного здійснення будь-якої професійної діяльності. I навпаки, оволодіння фахівцем спеціальними уміннями, зумовленими специфікою різних компонентів діяльності, підвищує рівень його стресостійкість. 


\section{Питання психології}

Виходячи 3 цього, професійну стресостійкість можна визначити як здатність людини протистояти негативному впливу стресових факторів професійної діяльності, зумовлену індивідуальним комплексом іiі вроджених i набутих властивостей та процесів, які забезпечують оптимальне успішне досягнення мети трудової діяльності в складній емоціогенній ситуації [1]. Зі сказаного вище випливає, що професійна стресостійкість $є$ окремим проявом психічної стійкості, що виявляється під час дії професійних стресових факторів $\mathrm{i}$ ï специфічність буде визначатися конкретним видом професійної діяльності.

3 метою вивчення психологічних характеристик стресостійкості студентів та фахівців різних соціономічних професій нами було проведено емпіричне дослідження, у якому взяло участь 198 студентів середніх та вищих навчальних закладів Чернівців та 214 фахівців, що працюють за різними соціономічними професіями; всього - 412 осіб. Студенти вузів склали 113 чоловік, а професійних училищ - 85 осіб. Вони навчаються за наступними професіями: фельдшер, медична сестра, продавець, офіціант, бармен, перукар, вчитель історії, юрист, соціальний педагог, психолог, вчитель початкових класів, вихователь дошкільної установи, філолог, лікар. Вибірку працюючих фахівців склали: вчителі початкових класів, вчителі-предметники, вихователі дитячих садків, помічники вихователя, завідувачі дитячого садка, психологи, соціальні педагоги, керівники департаментів, офіціанти, майстри манікюру, медсестри, продавці, юристи, лікарі.

Вік досліджуваних - від 15 до 47 років $(\mathrm{M}=21,91 ; \sigma=5,69)$. Середній вік фахівців $(\mathrm{M}=24,43 ; \sigma=5,58) \in$ істотно вищим, ніж студентів $\quad(\mathrm{M}=19,19 ; \quad \sigma=4,22) \quad(\mathrm{p} \leq 0,001)$. Серед досліджуваних було 104 чоловіків та 308 жінок.

У дослідженнях було використано методики експрес-діагностики рівня психоемоційної напруги (О.Копіна, К.Суслова, Є.Заїкін) та Бостонський тест стресостійкості [3; 6].

Методики діагностики рівня психоемоційної напруги включають в себе батарею тестів експрес-діагностики рівня психосоціального стресу Л.Рідера та діагностики пов'язаних 3 ним факторів: самооцінки здоров'я; задоволеності життям; задоволеності умовами життя; задоволення основних життєвих потреб. Шкалу стресу Л.Рідера ми застосували для оцінки ступеня психоемоційної напруги студентів у міжособистісних стосунках, під час виконання повсякденних обов'язків, навчання. Бостонський тест стресостійкості спрямований на вивчення стилю життя та виявлення стресостійкості особистості.

Результати перевірки психометричних властивостей використаних методик свідчать про їх високу надійність, специфічність, чутливість і валідність.

В дослідженні використано стандартизовані методи статистичної обробки даних: описову статистику (середнє, стандартне відхилення, частоти), однофакторний дисперсійний аналіз для незалежних груп із застосуванням програми SPSS версія 21.00. Перевірка нормальності розподілу даних здійснювалася на основі тесту Колмогорова-Смирнова. Розподіл за всіма шкалами $\epsilon$ нормальним ( $\mathrm{p}>0,05)$.

Порівняльний аналіз рівнів задоволення здоров'ям, життям, умовами життя та основних життєвих потреб студентів та фахівиів соиіономічних професій.

Проаналізуємо, передусім, рівень самооцінки здоров'я сучасних студентів, адже, на думку авторів методики, низька самооцінка здоров'я пов'язана 3 підвищеним рівнем стресу, низькими показниками задоволення життям. Дані, наведені нижче на рис. 1 та у таблиці 1.показують, що сучасні студенти, в основному, задоволені своїм здоров'ям, оцінюючи його стан як добрий або дуже добрий. $\mathrm{He}$ виявлено студентів, які б оцінювали стан власного здоров'я як дуже поганий.

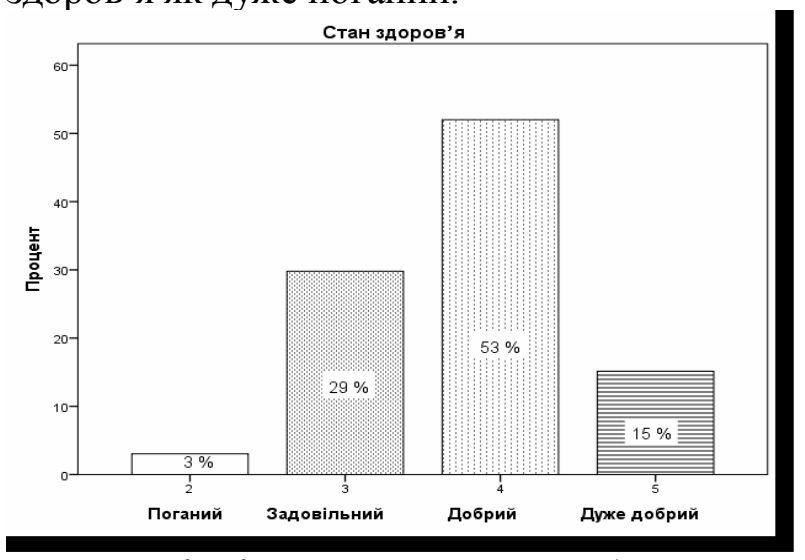

Рис. 1. Кількісні показники задоволення студентів власним здоров'ям (\%) 


\section{Питання психології}

Також для сучасних українських студентів як вищих, так i середніх навчальних закладів, характерними $\epsilon$ високий рівень задоволення життям, умовами життя та основних життєвих потреб, незважаючи на складні соціальноекономічні умови в країні. Однак порівняльний аналіз отриманих даних за типами навчальних закладів показав, що студенти закладів вищої освіти більше задоволені життям в цілому, але менше умовами життя $\mathrm{i}$ рівнем задоволення основних потреб, порівняно зі студентами професійних училищ.

Таблиця 1

Показники методик за типами навчальних закладів ( $\mathrm{N}=198)$

\begin{tabular}{|l|c|c|c|}
\hline \multicolumn{2}{|c|}{ Показники } & Студенти 3ПО & Студенти 3ВО \\
\hline \multirow{2}{*}{ Рівні задоволення здоров'ям } & $\mathrm{M}$ & 3,82 & 3,77 \\
\cline { 2 - 4 } & $\sigma$ & 0,83 & 0,65 \\
\hline \multirow{2}{*}{ Рівні задоволення життям в цілому } & $\mathrm{M}$ & 6,93 & 8,83 \\
\cline { 2 - 4 } & $\sigma$ & 4,14 & 4,43 \\
\hline \multirow{2}{*}{\begin{tabular}{l} 
Рівні задоволення умовами життя \\
Рівні задоволення основних життєвих \\
\cline { 2 - 4 } потреб
\end{tabular}} & $\mathrm{M}$ & 57,59 & 53,53 \\
\cline { 2 - 4 } & $\mathrm{M}$ & 6,79 & 6,68 \\
\cline { 2 - 4 } & $\sigma$ & 47,06 & 44,54 \\
\hline
\end{tabular}

Примітки: ЗПО - заклад професійної освіти, ЗВО -заклад вищої освіти.

Однофакторний дисперсійний аналіз для незалежних груп показав, що за усіма досліджуваними шкалами вибірки студентів закладів вищої та професійної освіти статистично відрізняються між собою:

- задоволення життям в цілому: $\mathrm{t}(196)=3,07 ; \mathrm{p} \leq, 01 ; \mathrm{d}$ Cohena $=0,44$;

- задоволення умовами життя: $\mathrm{t}(196)=4,19 ; \mathrm{p} \leq 0,001 ; \mathrm{d}$ Cohena $=0,59$;

- задоволення основних життєвих потреб: $\mathrm{t}(196)=3,73 ; \mathrm{p} \leq 0,001 ; \mathrm{d}$ Cohena $=0,53$.

Порівняльний аналіз отриманих даних за статтю не виявив статистично значущих відмінностей між хлопцями та дівчатами $(\mathrm{p} \geq 0,05)$.

Далі ми порівняли отримані за методикою Л. Рідера результати 3 дослідженнями фахівців, що працюють за соціономічними професіями. Результати аналізу представлено в таблиці 2.

Таблиця 2

Порівняльний аналіз стресостійкості студентів та фахівців за методикою Л. Рідера (N=412)

\begin{tabular}{|l|c|c|c|c|}
\hline \multirow{2}{*}{\multicolumn{1}{|c|}{ Показники }} & \multicolumn{2}{|c|}{ Студенти } & \multicolumn{2}{c|}{ Фахівці } \\
\cline { 2 - 5 } & M & $\sigma$ & M & $\sigma$ \\
\hline Рівні задоволення здоров'ям & 3,79 & 0,72 & 3,27 & 0,63 \\
\hline Рівні задоволення життям в цілому & 8,02 & 2,40 & 6,38 & 3,63 \\
\hline Рівні задоволення умовами життя & 55,27 & 7,01 & 48,92 & 5,93 \\
\hline Рівні задоволення осн. життєвих потреб & 45,62 & 5,04 & 41,89 & 5,53 \\
\hline
\end{tabular}

Ha основі критерію t-Student встановлено, що за усіма досліджуваними шкалами вибірки студентів та фахівців статистично відрізняються між собою:

- задоволення здоров'ям - t $(410)=7,63$; $\mathrm{p} \leq 0,01 ; \mathrm{d}$ Cohena $=0,76$;

- задоволення життям в цілому $\mathrm{t}(410)=3,25 ; \mathrm{p} \leq 0,001 ; \mathrm{d}$ Cohena $=0,32$;

- задоволення умовами життя - $\mathrm{t}$ $(410)=9,88 ; p \leq 0,001 ; d$ Cohena $=0,98$;

- задоволення основних життєвих потреб $\quad-\mathrm{t} \quad(410)=7,14 ; \quad \mathrm{p} \leq 0,001 ;$ $\mathrm{d}$ Cohena $=0,71$.

Порівняльний аналіз отриманих даних показав, що студенти більше задоволені своїм здоров'ям $(\mathrm{M}=3,79 ; \quad \sigma=0,72), \quad$ ніж фахівці $(\mathrm{M}=3,27 ; \quad \sigma=0,63)$. Також вони більше задоволені умовами життя та рівнем задоволення основних життєвих потреб, ніж фахівці (див. табл. 1-2). Критерій d Cohena за названими шкалами знаходиться в межах від 0,71 до 0,98 , що свідчить про сильний зв'язок між групами студентів і фахівців та досліджуваними шкалами $(\mathrm{p} \leq 0,01)$.

Також студенти більше задоволені життям в цілому. Виявлені відмінності можна пояснити особливостями вікового розвитку досліджуваних.

Порівняльний аналіз рівнів психосоціального стресу студентів за показниками тесту Л. Рідера.

Результати дослідження, наведені у таблиці 3 свідчать про те, що за рівнем психосоціального стресу досліджувані групи студентів істотно відрізняються між собою: $\mathrm{t}(196)=2,66 ; \mathrm{p} \leq 0,01 ; \mathrm{d}$ Cohena $=38$ (див. табл. 3). 


\section{Питання психології}

Таблиця 3

Показники психосоціального стресу студентів за типами навчальних закладів ( $\mathrm{N}=198)$

\begin{tabular}{|l|c|c|c|}
\hline \multicolumn{2}{|l|}{ Показники } & Студенти ЗПО & Студенти 3ВО \\
\hline Шкала психосоціального стресу & $\mathrm{M}$ & 1,32 & 1,11 \\
\cline { 2 - 4 } & $\sigma$ & 0,60 & 0,50 \\
\hline
\end{tabular}

Примітки: 3ПО - заклад професійної освіти, ЗВО -заклад вищої освіти.

Наведені вище результати дослідження свідчать про те, що у студентів закладів вищої освіти $(\mathrm{M}=1,11 ; \sigma=0,50)$ рівень психосоціального стресу $\epsilon$ достовірно нижчим, ніж у студентів закладів середньої освіти $(\mathrm{M}=1,32 ; \sigma=0,60)$.

Частотний аналіз результатів дослідження рівня психосоціального стресу за статтю, наведений у таблиці 4, показав, що для половини чоловіків $(55 \%)$

характерний низький рівень психосоціальної напруги, для $37 \%$ низький i лише для $8 \%$ чоловіків характерний високий рівень стресу. Схожа статистика виявлена у дівчат: переважаючим рівнем психоемоційної напруги для $52 \%$ студенток є середній, низький - для $43 \%$, високий - лише для 5 $\%$.

Таблиця 4

Показники с психосоціального стресу студентів за статтю (\%) $(\mathrm{N}=198)$

\begin{tabular}{|l|c|c|}
\hline Рівень & Хлопці & Дівчата \\
\hline Низький & 37 & 43 \\
\hline Середній & 55 & 52 \\
\hline Високий & 8 & 5 \\
\hline
\end{tabular}

На основі критерію t-Student встановлено, що за рівнем психоемоційної напруги досліджувані групи дівчат та хлопців статистично відрізняються між собою: $\mathrm{t}(196)=-1,97 ; \mathrm{p} \leq 0,05 ; \mathrm{d}$ Cohena $=0,28$. Для хлопців - M=1,12; $\sigma=0,52$, тоді як для дівчат $-\mathrm{M}=1,27 ; \sigma=0,58$. Це означає, що рівень психосоціального стресу у хлопців істотно вищий, ніж у дівчат.

Порівняльний аналіз проаналізованих вище результатів дослідження 3 дослідженнями фахівців, що працюють за соціономічними професіями показав, що за рівнем психосоціального стресу вибірки студентів та фахівців статистично відрізняються між собою: $\mathrm{t}(410)=-2,89$; $\mathrm{p} \leq 0,01 ; \mathrm{d}$ Cohena $=0,28$ (див. таблицю 5).

Таблиця 5

Порівняльний аналіз стресостійкості студентів та фахівців за методикою Л. Рідера

\begin{tabular}{|l|c|c|c|c|}
\hline \multirow{2}{*}{ Показники } & \multicolumn{2}{|c|}{ Студенти } & \multicolumn{2}{c|}{ Фахівці } \\
\cline { 2 - 5 } & $\mathrm{M}$ & $\sigma$ & $\mathrm{M}$ & $\sigma$ \\
\hline Шкала психосоціального стресу & 1,20 & 0,56 & 1,37 & 0,57 \\
\hline
\end{tabular}

Аналіз отриманих даних на основі критерію t-Student показав, що рівень психосоціального стресу виявився вищим у фахівців $(\mathrm{M}=1,37 ; \sigma=0,57)$, ніж у студентів $(\mathrm{M}=1,20 ; \quad \sigma=0,56) \quad(\mathrm{p} \leq 0,01) . \quad$ Виявлені відмінності можна пояснити особливостями вікового розвитку досліджуваних.

Порівняльний аналіз рівня стресостійкості студентів та фахівців за Бостонським тестом стресостійкості

Наступним кроком нашого дослідження став порівняльний аналіз рівня стресостійкості студентів. Для цього ми використали Бостонський тест стресостійкості. Результати аналізу представлено на рис. 2.

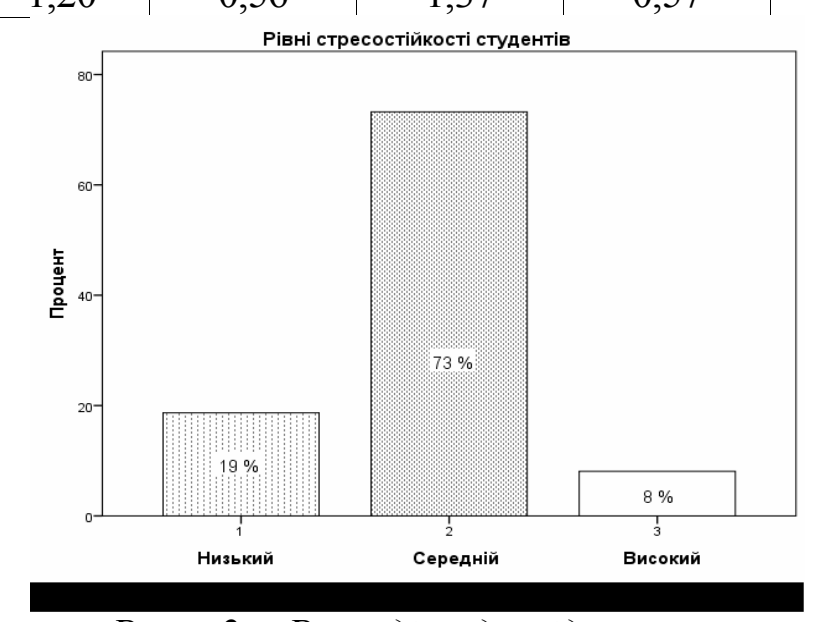

Рис. 2. Розподіл досліджуваних за рівнями стресостійкості (\%)

Наведені вище дані свідчать про те, що для більшості сучасних студентів характерним $\epsilon$ середній рівень 


\section{Питання психології}

стресостійкості, низький властивий близько $19 \%$ студентів, а високий - лише $8 \%$. Слід зазначити, що студенти 3 низьким рівнем стресостійкості можуть потребувати психологічної допомоги.

Наступним кроком нашого аналізу було порівняння досліджуваних груп студентів за статтю (див. табл. 6).

Аналіз стресостійкості студентів за статтю (N=198)

\begin{tabular}{|c|c|c|c|c|c|c|c|}
\hline \multirow{2}{*}{ Рівень } & \multicolumn{3}{|c|}{ Хлопці } & \multicolumn{3}{|c|}{ Дівчата } & \multirow{2}{*}{$\mathrm{p}$} \\
\cline { 1 - 8 } & $\%$ & $\mathrm{M}$ & $\sigma$ & $\%$ & $\mathrm{M}$ & $\sigma$ & \\
\cline { 1 - 7 } Низький & 17 & 54,44 & 3,52 & 20,5 & 58,05 & 7,08 & \\
\hline Середній & 78 & 36,45 & 7,99 & 68,5 & 36,33 & 8,75 & \multirow{2}{*}{0,91} \\
\hline Високий & 5 & 15,60 & 4,27 & 11 & 15,55 & 4,78 & \\
\hline
\end{tabular}

Дані частотного аналізу показують, що для більшості хлопців і дівчат властивим $€$ середній рівень стресостійкості, хоча серед дівчат більше осіб з високим i низьким рівнями стресостійкості, однак ці відмінності статистично не значущі ( $\mathrm{p} \geq 0,05)$.

Наведені у табл. 7 дані показують, що спільним для сучасних студентів закладів

вищої та середньої освіти є домінування середнього рівня стресосійкості, однак його відсоток значно вищий серед студентів вузів, ніж училищ (відповідно $65 \%$ та $80 \%$ ). Виявлено також, що студентів 3 низьким рівнем стресостійкості значно більше серед студентів закладів середньої освіти, ніж ЗВО (відповідно $35 \%$ і $6 \%$ ).

Таблиця 7

Аналіз рівнів стресостійкості студентів вищих та середніх навчальних закладів ( $\mathrm{N}=198)$

\begin{tabular}{|c|c|c|c|c|c|c|c|c|c|c|}
\hline \multirow{2}{*}{ Рівень } & \multicolumn{4}{|c|}{ ЗПО } & \multicolumn{4}{|c|}{$3 \mathrm{BO}$} & \multirow[b]{2}{*}{$t$} & \multirow[b]{2}{*}{$\mathrm{p}$} \\
\hline & $\mathrm{N}$ & $\%$ & $\mathrm{M}$ & $\sigma$ & $\mathrm{N}$ & $\%$ & M & $\sigma$ & & \\
\hline Низький & 30 & 35 & 56,93 & 6,36 & 7 & 6 & 54,57 & 4,15 & \multirow{3}{*}{$-9,93$} & \multirow{3}{*}{0,001} \\
\hline Середній & 55 & 65 & 41,64 & 6,56 & 90 & 80 & 33,19 & 7,68 & & \\
\hline Високий & 0 & 0 & 0 & 0 & 16 & 14 & 15,56 & 4,48 & & \\
\hline
\end{tabular}

Примітки: ЗПО - заклад професійної освіти, ЗВО - заклад вищої освіти.

Тривожним фактом є відсутність студентів з високим рівнем стресостійкості серед учнів професійних училищ, натомість серед студентів закладів вищої освіти їх близько 14 \%. Аналіз критерію t-Student показав статистичну значущість виявлених відмінностей: рівень стресостійкості студентів закладів вищої освіти $є$ істотно вищим $(\mathrm{M}=32,02, \sigma=9,78)$, ніж студентів закладів середньої освіти $(\mathrm{M}=47,04, \sigma=11,05)$.

Важливим кроком нашого дослідження стало порівняння рівня стресостійкості студентів та працюючих фахівців. Результати проведеного аналізу представлено в табл. 8 та на рис. 3 .

Рівні стресостійкості студентів та фахівців ( $\mathrm{N}=412)$

\begin{tabular}{|c|c|c|c|c|c|c|}
\hline \multirow{2}{*}{ Показники } & \multicolumn{2}{|c|}{ Студенти } & \multicolumn{2}{|c|}{ Фахівці } & \multirow{2}{*}{$\mathrm{t}$} \\
\cline { 1 - 5 } & $\mathrm{M}$ & $\sigma$ & $\mathrm{M}$ & $\sigma$ & & \\
\hline Стресостійкість & 38,46 & 12,87 & 30,83 & 9,43 & 6,81 & 0,001 \\
\hline
\end{tabular}

Наведені результати порівняльного аналізу стресостійкості студентів та фахівців показали суттєві відмінності між ними в кількісних проявах досліджуваних 3 низьким i високим його рівнями. $\mathrm{y}$ студентів домінуючим $\epsilon$ середній рівень стресостійкості, у фахівців - високий. Тобто 50,5 \% фахівців характеризуються високою стресостійкістю, тоді як серед студентів цей показник становить лише $28,3 \%$ вибірки. Близько 18,7 \% студентів властива низька стресостійкість, тоді як серед фахівців стресонестійких менше $1 \%$.

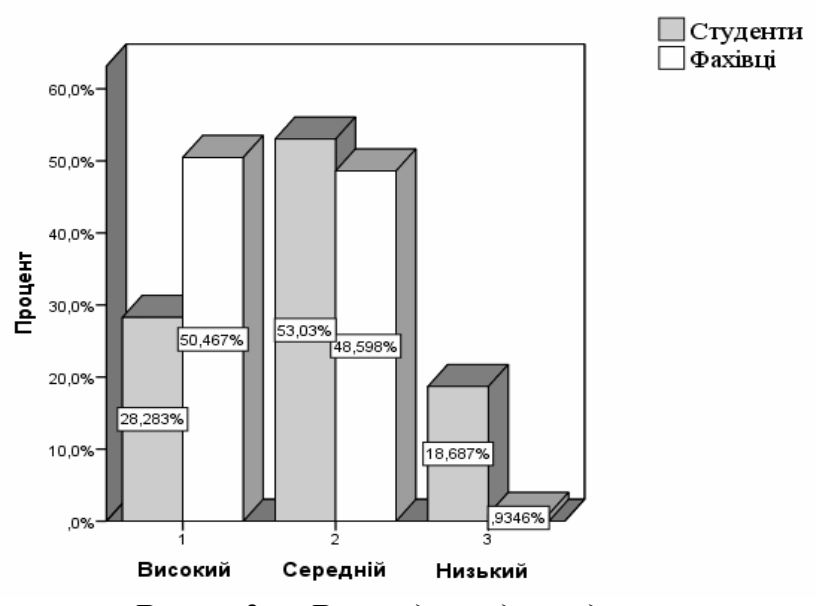

Рис. 3. Розподіл досліджууваних за рівнями стресостійкості (\%) 


\section{Питання психології}

Аналіз отриманих даних на основі критерію t-Student показав, що виявлені відмінності $\epsilon$ статистично значущими: $\mathrm{t}(410)=6,81, \mathrm{p}<0,001$. Слід наголосити, що при інтерпретації отриманих даних за Бостонським тестом стресостійкості слід враховувати зворотну залежність: чим вищий показник, тим нижчою $\epsilon$ стресостійкість. Це означає, що рівень стресостійкості фахівців $(\mathrm{M}=30,83, \sigma=9,43) \epsilon$ істотно вищим, ніж у студентів $(\mathrm{M}=38,46, \sigma$ $=12,87$ ). Аналіз критерію d Cohena $=0,72$ показав виражену залежність між рівнем стресостійкості та групами досліджуваних.

Висновки і перспективи подальших розвідок у даному напрямку. На основі узагальнення викладеного вище можна зробити наступні висновки:

Для сучасних українських студентів закладів вищої та середньої освіти характерним $\epsilon$ високий рівень задоволення життям, умовами життя та основних життєвих потреб. Однак, студенти ЗВО більше задоволенні життям в цілому, але менше умовами життя і рівнем задоволення основних потреб, порівняно зі студентами закладів середньої освіти. Аналіз даних дослідження за статтю не виявив істотних статистично відмінностей за досліджуваними шкалами. З'ясовано, що

студенти більше задоволені своїм здоров'ям, умовами життя, рівнем задоволення основних життєвих потреб та життям в цілому порівняно з фахівцями.

За рівнем психоемоційної напруги досліджувані групи істотно статистично відрізняються між собою: у студентів закладів вищої освіти рівень психосоціального стресу $\epsilon$ достовірно нижчим, ніж у студентів закладів середньої освіти. Також встановлено, що рівень психосоціального стресу у хлопців істотно статистично істотно вищий, ніж у дівчат. 3'ясовано, що працюючі фахівці характеризуються значно вищою стресостійкістю, порівняно зі студентами.

Таким чином, результати аналізу свідчать про те, що стресостійкість $\epsilon$ професійно важливою якістю фахівців соціономічних професій, а іiі становлення $\epsilon$ необхідною умовою ефективної професійної діяльності.

\begin{tabular}{lr}
\multicolumn{3}{c}{ Перспективними } & напрямками \\
подальших досліджень & вважаємо \\
дослідження психологічних особливостей \\
прояву професійної стресостійкості на \\
різних вікових етапах професійного \\
розвитку фахівця, зокрема, у відповідності \\
до шляху досягнення фахівцем \\
професіоналізму.
\end{tabular}

\section{Список використаних джерел:}

1. Дубчак Г.М. Розуміння професійної стресостійкості у психологічній літературі / Г. М. Дубчак // Науковий вісник Чернівецького університету : Збірник наукових праць. - Вип. 649. Педагогіка та психологія. - Чернівці : Чернівецький нац. університет, 2014. - С.39-47 $199 \mathrm{c}$.

2. Климов Е. А. Введение в психологию труда / Е. А. Климов. - М. : Изд-во Моск. ун-та, 1988. -

3. Копина О. С. Экспресс-диагностика уровня психоэмоциального напряжения и его источников / О. С. Копина, Е. А. Суслова, Е. В. Заикин. - Вопросы психологии. - № 3. - 1995. - С. 119-132.

4. Сердюк Л.3. Мотивація учіння особистості як детермінований та самодетермінований феномен // Збірник наукових праць: філософія, соціологія, психологія. - Івано-Франківськ: Вид-во ДВНЗ» Прикарпатський національний університет імені Василя Стефаника», 2015. - Вип. 20, ч.2. - 248 с. C.93-102.

5. Tomaszewski T. Człowiek w sytuacji / T. Tomaszewski // Psychologia ; [red. Tadeusz Tomaszewski]. - Warszawa : PWN, 1975. - $891 \mathrm{~s}$.

6. Щербатых Ю.В. Психология стресса и методы коррекции / Ю.3. Щербатых. - СПб.: Питер, 2006. $-256 \mathrm{c}$.

\section{References}

1. Dubchak G.M. Rozuminnya profesijnoyi stresostijkosti u psy`xologichnij literaturi / G. M. Dubchak // Naukovy’j visny'k Chernivecz'kogo universy `tetu : Zbirny'k naukovy`x pracz'. - Vy`p. 649. Pedagogika ta psy`xologiya. - Chernivci : Chernivecz ky'j nacz. universy`tet, 2014. - S.39-47 $-199 \mathrm{~s}$.

2. Kly`mov E. A. Vvedeny`e v psy`xology`yu truda / E. A. Kly`mov. - M. : Y`zd-vo Mosk. un-ta, 1988. 


\section{Питання психології}

3. Kopy`na O. S. Эkspress-dy`agnosty`ka urovnya psy`xoэmocy`al’nogo napryazheny`ya y` ego y`stochny kov / O. S. Kopy`na, E. A. Suslova, E. V. Zay'ky`n. - Voprosы psy`xology’y`. - \# 3. - 1995. - S. 119-132.

4. Serdyuk L.Z. Moty`vaciya uchinnya osoby`stosti yak determinovany`j ta samodeterminovany`j fenomen // Zbirny`k naukovy`x pracz' : filosofiya, sociologiya, psy`xologiya. - Ivano-Frankivs 'k: Vy’d-vo DVNZ» Pry`karpats 'ky`j nacional’ny’j universy`tet imeni Vasy'lya Stefany`ka», 2015. - Vy`p. 20, ch.2. - 248 s. - S.93-102.

5. Tomaszewski T. Człowiek w sytuacji / T. Tomaszewski // Psychologia ; [red. Tadeusz Tomaszewski]. - Warszawa : PWN, 1975. - $891 \mathrm{~s}$.

6. Shherbatox Yu.V. Psy`xology’ya stressa y` metodb korrekcy`y` / Yu.Z. Shherbatox. - SPb.: Py`ter, 2006. $-256 \mathrm{c}$.

\section{SUMMARY \\ Dubchak G., Dr. of Science (Psychology) \\ Serdiuk L., Dr. of Science (Psychology), Professor \\ COMPARATIVE ANALYSIS OF STRESS RESISTANCE FEATURES \\ OF STUDENTS AND SPECIALISTS OF SOCIONOMIC PROFESSIONS}

The article substantiates the relevance of studying the problem of professional stress resistance of specialists of socionomic professions. The content of the concept "professional stress-resistance" is explained. The article describes the procedure of the study with the use of the method of express diagnostics of the level of psychoemotional tension (O.Kopina, K.Suslova, E.Zaikin, 1995) and the Boston stress-resistance test.

The paper presents the results of the empirical study of the features of stress and psycho-emotional tension among students of socionomic profile and working professionals. There were determined the common and distinctive features of stress resistance of future and working specialists of various socionomic professions.

It is revealed that modern Ukrainian students from higher and secondary educational institutions have a high level of satisfaction with life, living conditions and basic vital needs. However, university students are more satisfied with life in general, but less with living conditions and the level of satisfaction of their basic needs compared with students in secondary education. Analysis of the survey data showed no statistically significant differences between genders. It has been found that students are more satisfied with their health, living conditions, and the level of satisfaction of their basic needs and life in general compared with specialists.

By the level of psycho-emotional tension the study groups vary significantly: among students of institutions of higher education the level of psychosocial stress is significantly lower than among students of secondary education institutions. It was also found that the level of psychosocial stress is significantly higher among boys than among girls. It was revealed that working specialists are featured by significantly higher stress resistance in comparison to students.

The results of the analysis indicate that stress is a professionally important quality of specialists of socionomic professions, and its formation is a prerequisite for effective professional activity.

Keywords: professional training, socionomic professions, stress, professional stress, level of mental tension. 